\section{Evaluation of instruments for the use of a condom} REVIEW

\section{Abstract}

Introduction: The usage of scales directed to the health area is a relevant contribution to clinical practice, because the measures are more reliable and standardized.

Objective: To analyze the studies that used scales to assess condom use.

Method: It is an integrative review, which was conducted in the CINAHL, Medline and Scopus databases, obtaining the selection of eight papers.

Results: The results pointed the appearance of three categories: Self-efficacy and usage of the condom, attitude and skill to the usage of the condom and barriers to the usage of the condom.

Conclusion: The validated scales found in literature deal with concepts and aspects that influence condom use and subsidize the practice of nursing professionals to identify condom use, contributing in the directed assessment of sexual behavior.
Carla Suellen Pires de Sousa1, Eveliny Silva Martins ${ }^{2}$, Anaíze Viana Bezerra de Menezes ${ }^{1}$, Maria Lúcia Duarte Pereira1, Luana Ibiapina Cordeiro', Ana Karina Bezerra Pinheiro², Priscila de Souza Aquino², Régia Christina Moura Barbosa²

1 State University of Ceará (UECE), Fortaleza, CE, Brazil.

2 Federal University of Ceará (UFC) Fortaleza, CE, Brazil.

\section{Contact information:}

\section{Carla Suellen Pires de Sousa}

Address: Dr. Silas Munguba Avenue, 1700, State University of Ceará, Fortaleza, CE, Brazil.

Departament of nursing, State University of Ceará.

”carla_suellenps@hotmail.com

Keywords

Condom; Scales; Validation; Studies.

\section{Introduction}

The sexuality is a human need of sociocultural construction influenced by values and beliefs that depend on the time and space in wich we live, and related to the sexual relations that are characterized by a sexual division of power, that, to many couples, the sex without protection can be seen as a moment of intimacy and trust, what will allow the creation of a barrier to the usage of condoms[1,2].

In perspective of realize the integral health care, approach sexual aspects, include inputs of prevention and provide an assistance focused on the preventive aspects,started the politics of free condom distribution to the health services[3].

In Brazil, in 1994, the politics of free distribution 
of condoms to the health care services started aiming to realize an integral health care, to approach sexual aspects, to include inputs of prevention and to provide assistance focused on the preventives aspects[3].

The no adherence to the usage of condoms is still an observed reality, predominantly, in teenagers and in young adults of both sexes, because of the biopsychosocial changes that happen in this phase of life, related to wishes, doubts and curiosities, which makes them more vulnerable to undesired and/or precocious pregnancy and to the Sexuality Transmitted Infections (STI), like the HIV/aids, which still is considered a problem of global public health[4,5,6].

According to data from the National Research of Health of the Student, one out of four teenagers that started the sexual life did not use condoms and are exposed to the risks of STI[7].

In Latin America, the Program of Group of the United Nations about HIV/aids (UNAIDS) estimated that around 450 thousand women are living with HIV in 2013, caused by unprotected sex, while in Brazil the estimation is almost half of it, 210 thousand women. Evidences have pointed to an increase in the rate of infection, registrating 4118 new cases in the young population from 15 to 24 years, regardless of the economical factor[8,9].

The elaboration of interventions for the adaption of preventive measures faces, sometimes, difficulties in evaluating the real needs of a population. The usage of condoms is a theme that is hard to discuss and requires the coping of social, cultural and emotional barriers[10].

It is considered the usage of scales directed to the health area a relevant contribution to the clinical practice, because of the advantages contained in these measure tools, in the interest of researchers in its utilization to collectinformation from the population as a hole in different contexts, in view of the submission to the process of validation that makes them valid and reliable[11].

On the above, this investigation aimed to analyze the studies that used scales to evaluate the usage of condoms

\section{Methods}

In the search of scales that approached the usage of condoms, an integrative review of literature was realized, what made the comprehension of the studied phenomenon and the synthesis of the productions easier. Recommended steps were followed with methodological rigor, they are: 1) selection of the theme to be studied and elaboration of the guiding question; 2) identification of the descriptors in the databases and establishment of inclusion/ exclusion criteria; 3) selection of the informations to be extracted from the texts and categorization of the studies; 4) evaluation of the studies include in the review; 5) interpretation of the results; 6) presentation of the revision/synthesis of the knowledge[12]

The theme of interest chosen was validated scales that approached the usage of condoms. The guiding question to the elaboration of this research was: "Which scales have been used to assess condom use?"

The search was made in the following databases Medical Literature Analysis and Retrieval System On-line (MEDLINE), Cumulative Indox to Nursing and Allied Health Literature (CINAHL) and SCOPUS, Without delimitation of time for publications. The access to the databases occurred via the portal of periodicals from the Improvement of Senior Staff Coordination (ISSC), in August of 2016, it was performed by three researchers in different searches. The controlled describers utilized were "condom" and "scale" in an integrative manner in the three databases. We used two descriptors with the purpose to further expand the search for the papers of interest.

The following inclusion criteria were adapted: be an article of research; have a complete text availa- 
bleelectronically; being written in English, Spanish or Portuguese; contain pertinent information to the guiding question. All the articles that did not fit in the proposed criteria or that has been repeated in different databases were excluded.

Following the selection of papers, we proceeded to the full reading of these documents, and then the data were extracted and organized for analysis. In order to collect data of the works included in the review, we drew up an instrument based on the proposed for integrative review (URSI, 2005). The instrument encompassed the following aspects: title of the paper; year of publication; country of origin; journal; database; objectives of the scale; use of theory in the study, and also enabled us to list the items and to record information encompassed in its aspects.

\section{Results}

During the search in MEDLINE database, 600 articles were identified. After reading the summaries, five works were chosen one of them was repeated, resulting in four articles included in the review. In CINAHL database, 211 articles were found and four of them chosen after reading the titles and summaries available. However, three were repeated, having one article left for evaluation. In SCOPUS database, 838 works were found and six of them chosen after reading the tittles and summaries available. Two of these six were repeated and one was not about a valid tool, so only three were left to evaluation. Therefore, the result of the search was finished with the inclusion of eight articles. The selection of the articles to review was made by three researches. The informations about the search were disposed on chart 1.

After selection, eight articles were subjected to reading and its informations were grouped and inserted in the analysis. The goal of the analysis and interpretation phase is to synthesize the informa-
Chart 1. Selection of the articles of research in the databases according to the established inclusion criteria. Fortaleza, August, 2016.

\begin{tabular}{|c|c|c|c|}
\hline Database & Descriptor & $\begin{array}{c}\text { Obtained } \\
\text { Results }\end{array}$ & $\begin{array}{c}\text { Articles } \\
\text { included }\end{array}$ \\
\hline CINAHL & Condom; scale & 785 & 1 \\
\hline MEDLINE & Condom; scale & 513 & 4 \\
\hline SCOPUS & Condom; scale & 968 & 3 \\
\hline
\end{tabular}

Source: Labored by the authoress (2016).

tions registered in the tool and discuss them, grouping them in similar categories[12].

The characterization of the included articles in the review was organized in Table 1 . The presentation of the synthesis of the main results and discussion of the obtained data was made in a descriptively manner. Chosen articles were divided according to theoretical basis to approach the usage of the condom.

\section{Discussion}

After analyzing the studies, the results pointed to the appearance of three categories: Self-efficacy and usage of the condom, attitude and skill to the usage of the condom and barriers to the usage of the condom.

\section{Self-efficacy and use of the condom}

Scales based on the theory of self-efficacy to evaluate the usage of condoms are important tools regarding the relevant association of the theory with the use of the method. Thus, many researches used the Theory of Self-efficacy to develop scales that evaluate changes of behavior due to the use of condoms.

Two of the scales inserted in the review had their construct based on the Theory of Self- efficacy. Condom use self-efficacy scale built in the United States aimed to evaluate self-efficacy in the usage of the condom, initially it had 28 items, but after 
Table 1. Presentation of the chosen articles, according to title, publishment year, country, databases and goal of the study scale.

\begin{tabular}{|c|c|c|c|c|}
\hline Title & Year & Country & Database & ScaleGoal \\
\hline $\begin{array}{l}\text { Cross the cultural adaptation of the } \\
\text { short-form condom attitude scale: } \\
\text { validity assessment in a sub-sample } \\
\text { of rural-to-urban migrant workers in } \\
\text { Bangladesh. }\end{array}$ & 2013 & Bangladesh & Medline & $\begin{array}{l}\text { Translate and culturally adapt the Scale at } \\
\text { Attitudes regarding the usage at condoms. }\end{array}$ \\
\hline $\begin{array}{l}\text { The use of the Risky Sex Scale among } \\
\text { adolescents receiving treatment } \\
\text { services for substance use problems: } \\
\text { Factor structure and predictive validity. }\end{array}$ & 2012 & United States & Scopus & $\begin{array}{l}\text { Evaluate the usage of the Scale of risk } \\
\text { sex among the youngsters in outpatient } \\
\text { treatment to usage of substances. }\end{array}$ \\
\hline $\begin{array}{l}\text { Factor Structure of the Condoms } \\
\text { Barriers Scale With a Sample of Men at } \\
\text { High Risk for HIV. }\end{array}$ & 2009 & United States & Medline & $\begin{array}{l}\text { Evaluate noted barriers to usage of the male } \\
\text { condom. }\end{array}$ \\
\hline $\begin{array}{l}\text { Development of a scale for attitude } \\
\text { toward condom use for migrant } \\
\text { workers in India. }\end{array}$ & 2008 & India & Scopus & $\begin{array}{l}\text { Develop and validate scale to evaluate } \\
\text { attitude regarding the usage of the condom } \\
\text { and the subassembly of items from the } \\
\text { previously tested scale in a sample of works } \\
\text { in India. }\end{array}$ \\
\hline $\begin{array}{l}\text { A condom skill scale: assessing } \\
\text { condom skills among female drug } \\
\text { users. }\end{array}$ & 2003 & United States & Cinahl & $\begin{array}{l}\text { Describe the development of properties of } \\
\text { measure scales that show skill in the usage } \\
\text { of condoms with drug addicted women. }\end{array}$ \\
\hline $\begin{array}{l}\text { Developing a scale for measuring the } \\
\text { barriers to condom use in Nigeria. }\end{array}$ & 2001 & Nigeria & Medline & $\begin{array}{l}\text { Describe the development of scale to } \\
\text { measure barriers to the usage of condoms } \\
\text { in Nigeria and evaluate its content, viability, } \\
\text { reliability and validity. }\end{array}$ \\
\hline $\begin{array}{l}\text { An adolescent and young adult } \\
\text { condom self-efficacy scale }\end{array}$ & 1999 & United States & Medline & $\begin{array}{l}\text { Build and validate self-efficacy scale to the } \\
\text { usage of condoms among teenagers and } \\
\text { young adults. }\end{array}$ \\
\hline $\begin{array}{l}\text { Development and Validation of a } \\
\text { Condom Self-Efficacy Scale for College } \\
\text { Students }\end{array}$ & 1991 & United States & Scopus & $\begin{array}{l}\text { Develop and validate scale for university } \\
\text { population that measures self-efficacy in } \\
\text { the usage of the condom. }\end{array}$ \\
\hline
\end{tabular}

Source: Labored by the authoress (2016).

content of validation only 15 items were left, and they describe feelings of assurance of the individual about being capable of buying condoms, use it correctly and negotiate the use with a new sexual partner[14].

The scale was evaluated by five experts that had worked with university students in the field of sexuality and students also participated in the construction of the scale, what makes the comprehension of target the tool by the target audience easier. In the construct analysis, the scale was applied to 768 students, obtaining the alpha of Cronbach of 0,91 and in the test-retest the valve of 0,81 was obtained. The Condom Use Self-Efficacy Scale demonstrated pertinent psychometrical properties, making it a valid and reliable too that can be used in the educational context (BRAFFORD; BECK, 1991). It is also noted that, posteriorly, the scale, given the relevance degree, the scale was adapted and validated in Ghana and Ethiopia[15,16].

The adapted and validated version of Condom Use Self-Efficacy Scale in Gana, after the process of validation, resulted in 14 items. The construct validation was applied to 511 students of both gen- 
ders. The scale presented high internal consistency of 0,91, similar to the original scale. The version of the Condom Use Self-Efficacy Scale in Ethiopia was adapted with nine items and applied to 492 students. It presented an alpha of Cronbach of 0,92. Thus, it is stated that the referred scale is valid and reliable in different cultures.

Another scale based in the Theory of Self-Efficacy was the Condom Self-Efficacy Scale (CSE), whose goal is to evaluate the usage of condoms among teenagers and young adults. Developed by a nurse from the University of Indiana in the United States, in 1999, it contains 14 items that evaluate communication, consistent and right use of the condom. The scale presented a value of alpha of Cronbach of $0,85[17]$.

The CSE was adapted and validated in Thailand with 425 students from 18 to 22 years, of eight professional schools. It remained with the same amount of items of the original scales and presented alpha of Cronbach of 0,85[18].The referred scale was also considered valid and reliable to be used with youngsters from Korea. The validation of the construct occurred in a sample of 351 students from 18 for 25 years from an university from the South of Korea. The alpha coefficient of Cronbach to the scale was 0,91, bigger than the one from the original scale[19].

\section{Attitude and skill to the usage of condoms}

Attitude regarding the use of the condom was a theme approached by two scales of the chosen studies. Attitude is an important and indispensable behavior to the use of the condom. Can be considered as having feelings, will and beliefs directed to a goal or situation[20]. The Condom Attitude Scale (CAS-B) was adapted and validated to rural workers in Bangladesh, because there was no uniform and standardized attitude scale to the usage of condoms. The scale has the goal of evaluate attitude regarding the use of the condom among vulnerable groups from the population of Bangladesh (CAS-B).
It is composed by ten items and divided in three dimensions: preservative and sexual satisfaction; preservative and gender dimension; preservative and sexual interest. The scale was applied in a sample of 878 men, from 18 to 35 years, with the alpha of Cronbach of 0.89. Attitude regarding the usage of condoms was measured with items like Likert. The scale is bidirectional, because it includes both positive and negative attitudes regarding the use of condoms[21].

The scale Attitude Towars Condom (ATC) evaluates the attitude regarding the usage of the condom, validated among workers from India. It is constituted of 10 items that evaluate positive and negative perceptions beliefs regarding the use of condoms. The sample to construct validate was composed by 514 men, migrant workers from India, from 18 to 49 years. The scale structure was explored by the analysis of main components, followed by the analysis of the Varimax Rotation. It presented alpha of Cronbach of 0.92[22]. This scale was considered valid to be used in the population of India.

The skill to the use of condoms was measured by the Condom Skill Scale (CSS), validatedin a sample of 261 drug users. Skill is understood as a way to use knowledge to solve conflict situations and have creativity to create new strategies[23]. The scale was developed in the United States in 2003, it measures the correct use of condoms and evaluates the skill in the use of the method aiming to diminish failures arising from its incorrect use. It is a valid and reliable scale, with an alpha of Cronbach of 0.91[24]. Many studies approach this triad, knowledge, attitude and practice regarding the use of condoms[25,26]. The existence of these measure tools contributes in a satisfactory way in order to measure the constructs that in many times are very subjectives.

\section{Barriers to the usage of the condom}

The Condom Barriers Scale (CBS) has 29 items and was developed, at first, for prevention of the STD/HIV/aids in NorthAmericans. The same is divid- 
ed in four components: (1) barriers regarding the partner, (2) effects about the sexual experience, (3) access and availability, and (4) motivational barriers. The items are evaluated in a Likert scale that varies from 1 (totally agree) to 5 (totally disagree). The same was validated in a group of 278 women and presented an alpha of Cronbach of 0.86[27].

Posteriorly, the CBS was adapted to be used in the male population of the United States. The same was applied to 590 men that presented risk to obtain HIV/aids. During process of adaptation, ten items were modified. In the validation of construct was made a confirmatory factor analysis and the alpha of Cronbach was 0.90. Overall, the results suggest that the CBS is potentially a valid and reliable tool to men and women, and can be of use to evaluate barriers to the usage of condoms[28].

Another tool that also evaluates barriers to the use of condoms is the scale developed in Nigeria, titled Scale for Measuring the Barriers to Condom Use[29]. The scale has 22 items, being constituted of three dimensions: sexual satisfaction and condom; danger to health and condom; sexual interest and condom. Items referring to the sexual satisfaction and condom evaluate reduction in the sexual desire and satisfaction; inability of enjoying orgasms and uncomfortable sexual relation. Items that deal with danger to the health and condom evaluate tendency of the individual to report itching caused by the condom and irritation of the skin after sexual relation. Items that refer to the sexual interest and condom evaluate embarrassment that the individual shows after buying a condom and the inability of negotiate the use of the method with the sexual partner. It was used a sample of 786 students in the University of Ibadan, in Nigeria. In the validation of the construct was made a test-retest with a value of alpha of Cronbachof 0.88 . The scale can be used to evaluate factors that difficult use of condoms in the sexual relations, being valid to determine predisposition of the people to use condoms in future sexual meetings[29].
The use of the Risky Sex Scale (RSS) among youngsters in outpatient treatment for problems in the use of substances was evaluated by one of the related studies. The original scale is a brief screening tool developed and validated to university students, it has 14 items and an alpha of Cronbach of 0.85 . It has as a goal evaluate three domains of participation of the young adults in the sexual risk behavior; (1) expectations to sexual excitement and performance after consumption of alcohol; (2) risk sexual behavior in an alcoholic state; (3) perceptions of risk related to gender to sexual violence after the use of alcohol. Each item is evaluated in Likert scale that varies from 1 (totally disagree)to 5 (totally agree). Validation of construct was made with 394 teenagers of both genders, that received treatment for abuse of substances in two clinics in the south of Florida. The value of the alpha of Cronbach was 0.85[24].

\section{Conclusions}

Through this review, it was possible to notice that the use of validated measurement scales is a resource that subsidizes the practice of nursing professionals to identify condom use.

These instruments, reliable and valid, enable us to measure several subjective aspects that influence condom use. Self-efficacy, attitude, skill and barriers to condom use were the concepts and factors that subsidized the development of the identified scales.

The validated scales found in literature deal with concepts and aspects that influence condom use and contribute in the directed assessment of sexual behavior. In addition, the scales encompassed adolescents and young adults, which raised great interest because the investigation in this population is of utmost importance to subsidize specific nursing interventions for this group. 


\section{References}

1. Ministério da Saúde (BR). Secretaria de Atenção à Saúde. Departamento de Atenção Básica. Saúde sexual e saúde reprodutiva. Brasília: Ministério da Saúde; 2013. http:// bvsms.saude.gov.br/bvs/publicacoes/saude sexual saude reprodutiva.pdf

2. LaCroix JM, Pellowski JA, Lennon CA, Johnson BT. Behavioral interventions to reduce sexual risk for HIV in heterosexual couples: a meta- analysis. Sex TransmInfect. 2013; 89 (8):620-7. http://www.ncbi.nlm.nih.gov/pubmed/23918756.

3. Reis RK, Melo ES, Gir E. Factors associated with inconsistent condom use among people living with HIVIAIDS. RevBrasEnferm. jan-fev 2016; 69(1): 47-53.

4.http://www.scielo.br/pdf/reben/v69n1/0034-7167reben-69-01-0047.pdf.

5. Bezerra EO, Chaves ACCP, Pereira MLD, Melo FRG. Análise da vulnerabilidade sexual de estudantes universitários ao HIVIAIDS. Rev Rene. 2012;13(5): 1121-31. http://www.revistarene.ufc.br/ revista/index.php/revista/article/view/1167.

6. Almeida SA, Nogueira JA, Goldfarb MPL, Batista FL, Barrêto AJR, Moreira ASP et al. Concepção de jovens sobre o HIVIAIDS e o uso de preservativos nas relações sexuais. Rev Gaúcha Enferm. mar. 2014;35(1):39-46. http://www.scielo.br/pdf/rgenf/v35n1/ pt 1983-1447-rgenf-35-01-00039.pdf.

7. Silva MRB, Santos ME, Silva LA, Filho VF, Maturana HCA, Silva RB. Why they do not use?:a study about the accession of Adolescents not contraceptive methods and their Implications. Rev Saúde em redes. 2015;1(4): 75-83. http://dx.doi.org/10.18310/24464813.2015v1n4p75-83.

8. Brasil. Ministério do Planejamento, Orçamento e Gestão. Instituto Brasileiro de Geografia e Estatística-IBGE. Diretoria de Pesquisas. Coordenação de População e Indicadores Sociais. Pesquisa Nacional de Saúde do Escolar 2012. Rio de Janeiro: IBGE; 2013. http://biblioteca.ibge.gov.br/visualizacao/livros/liv64436.pdf

9. World Heath Organization. Global Reports: UNAIDS report on the global AIDS epidemic 2014. Geneva, 2014

10. http://www.unaids.org/sites/default/files/media_asset/ GARPR_2014_guidelines_en_0.pdf.

11. Centers for Disease Control and Prevention (CDC). Diagnoses of HIV infection in the United Sates and Dependent Areas, 2013.National Center for HIV/AIDS, Viral Hepatitis, STD, and TB Prevention, Departamento of Health and Human Services. USA: CDC, 2015. http://www.cdc.gov/hiv/pdf/library/reports/ surveillance/cdc-hiv-surveillance-report-vol-25.pdf

12. Dourado I, Carthy SM, Manasa R, Calazans G, Gruskin S. Revisiting the use of condoms in Brazil. Rev. Brasil. Epidemiologia. 2015;18(I):63-88. http://www.scielo.br/scielo.php?script=sci_ arttext\&pid=S1415-790X2015000500063.

13. Parra DI, Bayer GLA. Validez y confiabilidad de las escalas de comunicación y coordinación para medir rol interdependientemenfermaria. Avances em Enfermeria. 2010; 28(1):51-62. http://revistas.unal.edu.co/index.php/avenferm/ article/view/15627

14. Mendes, KDS, Silveira RCCP, Galvão CM. Revisão integrativa: método de pesquisa para a incorporação de evidências na saúde e na enfermagem. Texto Contexto Enferm Florianopólis. 2008;17(4):758-64. http://dx.doi.org/10.1590/S0104$\underline{07072008000400018}$

15. Ursi ES, Galvão CM. Prevenção de lesões de pele no período perioperatório: revisão integrativa da literatura. Rev Latino-Am Enfermagem [Internet]. 2006;14:124-31. Available from: http:// www.scielo.br/pdf/rlae/v14n1/v14n1a17.pdf

16. Brafford LJ, Beck KH. Development and validation of a condom self-efficacy scale for college students.J Am Coll Health.1991; 39(5): 219-25.http://www.ncbi.nlm.nih.gov/pubmed/1783705.

17. Asante KO, Doku PN. Cultural adaptation of the condom use self efficay scale (CUSES) in Ghana. Public Health.2010; 10: $\quad$ 2-7.http://bmcpublichealth.biomedcentral.com/ articles/10.1186/1471-2458-10-227.

18. Shaweno D, TekletsadikE. Validation of the condom use selfefficacy scale in Ethiopia. Intern. Health\& Human Rights.2013; 13:2-8. http://bmcinthealthhumrights.biomedcentral.com/ articles/10.1186/1472-698X-13-22.

19. Hanna KM. An adolescent and yong adult condom self-efficacy scale. Journal of Pediatric.Nursing. 1999; 14(1): 59-66. http:// www.ncbi.nlm.nih.gov/pubmed/10063250.

20. ThatoS, Hanna KM., Rodcumdee B. Translation and validation of the condom self-efficacy scale with thai adolescents and Young adults. Journal of nursing sholarship.2005; 37(1): 36-40. http:// www.ncbi.nlm.nih.gov/pubmed/15813585.

21. Cha SE, Kim KH, Buke LE. Psycometric validation os a condom self-efficay scale in Korean. Nurse rearch. 2008; 57(4): 245-51. http://www.ncbi.nlm.nih.gov/pubmed/18641493.

22. Marinho LAB, Gurgel MSC, Cecatti JG, Osis MJDO. Conhecimento, atitude e prática do auto-exame das mamas em centros de saúde. Rev Saúde Pública. 2003; 37(5): 57682. http://www.scielo.br/scielo.php?script=sci_arttext\&pid $=$ S0034-89102003000500005.

23. Roy T, Anderson C,EvansC, Rahman MS, RahamanS. Crosscultural adaptation of the short-form condom attitude scale: validity assessment in a sub-sample of rural-tourban migrant workers in Bangladesh. Public.Health.2013; 13: 2-10. http://bmcpublichealth.biomedcentral.com/ articles/10.1186/1471-2458-13-240.

24. Talukdar A, Bal R, SanvalD, Roy K, Talukdar PS. Development of a scale for attitude toward condom use for migrant workers in India. Indian J. Med. Sci. 2008; 62(2):55-61. http://www.ncbi. nlm.nih.gov/pubmed/18319532

25. Mascarenhas AO. Gestão estratégica de pessoas. Evolução, teoria e crítica. São Paulo: CengageLeanirg. 2008.

26. Farris CA, Fenaughty AM., Lindemann DF. A condom skill scale: assessing condom skills among female drug users. J. 
Drug. Educ. 2003; 33(2):217-31. http://www.ncbi.nlm.nih.gov/ pubmed/12929711.

27. Nicolau AIO, Ribeiro SG, Lessa PRA, Monte AS, Bernardo EBR, Pinheiro AKB. Conhecimento, atitude e prática do uso de preservativos por presidiárias: prevenção das DST/HIV no cenário prisional. Rev Esc. Enferm. USP. 2012; 46(3): 71119.http://www.scielo.br/scielo.php?script=sci arttext\&pid $=$ S0080-62342012000300025

28. Jardim DP, Santos EF. Uso do preservativo masculino por adolescentes no início da vida sexual. Adolesc. Sáude. 2012; 9(2): 37-44. http://www.adolescenciaesaude.com/detalhe artigo.asp?id=314.

29. Lawrence JS, Chapdelaine AP, Devieux JG, O'bannon RE, Eldiridge GD. Measuring perceived barriers to condom use: psychometric evolution of the Condom Barriers Scale. Rev. Assessment. 1999;6(4): 391-404. http://www.ncbi.nlm.nih.gov/ pubmed/10539985.

30. Doyle SR, Calsyn DA, Ball SA. Factor structure of the Condoms Barriers Scale with a sample of men at high risk for HIV.Rev. Assessment. 2009; 16(1): 3-15. http://www.ncbi.nlm.nih.gov/ pubmed/18689777.

31. Sunmola AM. Developing a scale for measuring the barriers to condom use in Nigeria.Bull World Health Organ. 2001; 79(10): 926-32. http://www.scielosp.org/scielo.php?pid=S0042$\underline{96862001001000005 \& \text { script=sci_arttext }}$

Publish in International Archives of Medicine

International Archives of Medicine is an open access journal publishing articles encompassing all aspects of medical science and clinical practice. IAM is considered a megajournal with independent sections on all areas of medicine. IAM is a really international journal with authors and board members from all around the world. The journal is widely indexed and classified Q2 in category Medicine. 